\title{
Culture Shock: A Review of the Literature for Practitioners*
}

\author{
Adrian Furnham \\ Norwegian Business School, Oslo, Norway \\ Email: adrian@adrianfurnham.com
}

How to cite this paper: Furnham, A. (2019). Culture Shock: A Review of the Literature for Practitioners. Psychology, 10, 1832-1855.

https://doi.org/10.4236/psych.2019.1013119

Received: September 16, 2019

Accepted: October 22, 2019

Published: October 25, 2019

Copyright () 2019 by author(s) and Scientific Research Publishing Inc. This work is licensed under the Creative Commons Attribution International License (CC BY 4.0).

http://creativecommons.org/licenses/by/4.0/

\section{(c) (i) Open Access}

\begin{abstract}
This paper considers the research on the ever-popular concept of culture shock and related ideas. Researchers from different disciplines (anthropology, education, psychiatry, psychology, sociology) have attempted to operationalise the concept, measure it, and understand the process behind it, as well as develop strategies to help those who experience it. This paper also considers issues concerned with the measurement of adjustment as well as the various groups of travellers who can have serious culture shock difficulties. Implications of this research are considered. This integrative review summarises a range of theory and evidence relevant to the UN SDGs, in particular to SDG10 which includes facilitating safe regular and responsible migration and mobility of people, including through the implementation of planned and wellmanaged migration policies. It also considers practical implications which will be of interest to medical and educational practitioners, policy makers, charitable institutions and travellers themselves.
\end{abstract}

\section{Keywords}

Culture Shock, Adjustment, Adaptation, Competence

\section{Introduction}

The aim of this paper is the explore, review and critique the multi-disciplinary literature on the concept of culture shock which is the unexpected and often negative reaction of people to new environments. Whilst it touches on a wider literature on such things as intercultural contact and competence and the process of adaptation and adjustment to new cultures, it focuses on the short-term *This paper is dedicated to the memory of Stephen Bochner who was a pioneer in this field. It is an update and extension of Furnham (2011). Culture shock: Literature review, personal statement and relevance for the South Pacific. Journal of Pacific Rim Psychology, 4(2), 87-94 which was published nearly a decade ago. 
reaction of travellers. Its aim is primarily educational, aimed specifically at travellers and educators.

People have, and will, always travel to "far off lands", different countries and continents and possibly soon planets, for very different purposes. They go to convert, conquer, explore, trade, teach, learn, holiday and settle. Over the last century, the reduced costs and increased ease of short and long-distance travel have shown a dramatic rise in people's movements around the world. This means that although they do not anticipate experiencing it, more and more people are confronted with culture shock.

There are many ways to classify these travellers i.e. how long they go for (i.e. migrants vs. sojourners vs. tourists); how far they travel (near vs. far; familiar vs unfamiliar); their motives for movement (education, trade, expansion); the nature of stranger-host relations (friendly vs. antagonistic) etc. Furthermore, they are of interest to different academic disciplines like anthropology, economics, education, psychiatry, psychology and sociology. What they have in common is that they have to "adapt to the new environment": to learn new ways of behaving, feeling and thinking. This can be unexpected and demanding.

The data on the sheer number of people moving between countries is staggering. According to the UN High Commissioner for Refugees report for 2016, in all 65.6 million people are displaced worldwide; one person flees every 3 seconds, and over half of the world's refuges are children. It is estimated that currently around 400 million people are migrants (nearly $4 \%$ of the world population); there are currently 70 million refugees; that there are nearly 5 million foreign students; and that 1.3 billion people go abroad as tourists every year. The comparative ease and cheapness of travel means that these numbers are likely to increase. Two generations ago, people in all countries tended to stay where they were: now children need passports to travel abroad. This has resulted in what Moufakkir (2013) has described as the rapid implosion of the Third World into the First World with culture shock soon becoming culture unrest.

The sheer number or people moving around the earth for very different reasons presents challenge for the researcher: Chinese professional working in East Africa, Honduran migrants stuck in Mexican limbo; West Africans trying to cross the Mediterranean; young people volunteering to work abroad. They all experience shock of many kinds often with very severe consequences. Hence, researchers have tried to identify risk factors associated with culture shock in Asylum Seekers such as gender, employment status, urban experience, previous travel, language proficiency, PTSD, and perceived discrimination (Slonim-Nevo \& Regev, 2015).

Most people even experience some sort of culture shock when the go on holiday. Whilst some attempt to minimize contact with the locals/natives, others revel in the prospect of eating new food at different times of day, learning a few words of a foreign culture and seeing religious and political sights. Inevitably the more they travel the less the shock, although many report sudden shock and surprise about being confronted with beliefs and behaviours alien to their own 
(Furnham, 1984). The whole point of the concept of shock is that it is unexpected and often unpleasant. It can also have a sudden and profound impact on an individual's identity (Cupsa, 2018).

Massive migration movements have of course led to an interest in the "shock of being visited" namely attitudes to immigrants of many kinds (McGhee, 2006; McLaren \& Paterson, 2018). It has also resulted in the study of how groups of individuals react to acculturation through the processes either of integration, assimilation, separation or marginalisation (Sam \& Berry, 2010). There is also a particular interest in young migrants who are increasing in number (Titzmann \& Lee, 2018).

There are many types of sojourners namely people who go abroad for a select period: business people, diplomats, the armed forces, students, voluntary and aid workers, missionaries, etc. They may spend six months to over five years in "other countries" in order to do business; represent their country; protect others or instruct other armed forces; study; teach or advise locals; convert and proselytize, respectively. Others move for good; be they migrants or refugees. Further, there are new types of travelers such as "gap year" travelers who also experience by now well documented medical and psychological problems (Furuya-Kanamori et al., 2017).

One question of concern is whether different types of migrant or travelling groups experience culture shock differently. There seem to be no specific studies that have done a careful comparative analysis but an examination of the literature pin-points numerous factors that would lead one to expect this (Ward et al., 2001). Thus, there are demographic factors (age, education), personality factors (neuroticism, extraversion), ideology factors (religion, politics), etc which means that the culture shock experienced by a professional diplomat would be rather different from that of a refugee. However, it seems that these differences ae more quantitative than qualitative in the sense that it is the acuity and chronicity of the shock experience involved rather than there being very different types with different processes, though this an important topic to pursue.

Because it is important that sojourners adapt quickly and well so that they can function effectively many organisations attempt to prepare them for working in the new culture and dealing with culture shock (Cohen, 2007; Furnham, 2011; Ward, Bochner, \& Furnham, 2001). The cost to any business of sending staff to work abroad means that they have become very interested in the "management" of culture shock which they know inevitably occurs (Kocak, 2014). Indeed, Human Resource experts are very interested in what sort of people make effective expatriate leaders (Engle, Dimitriadi, \& Sadrieh, 2012; Lauring, Selmer \& Kubovcikova, 2017).

This paper will explore how people define and react to new situations: what predicts why some adapt better than others and how to help those maximize the opportunity that culture travel provides (Furukawa, 1997). It also considers tangentially also the research on ever increasing migrants and refugees (Crawley \& Skleparis, 2018; McLaren \& Paterson, 2019; Titzmann \& Lee, 2018) as well as 
sojourners (Geereaet, Li, Ward, Gelfand, \& Demes, 2019) and expatriates (Valenzuela \& Rogers, 2018) as well as the often ignored shock of being visited: namely a host person coming into contact with travelers to his or her home (McGhee, 2006).

There is a vast and growing literature on intercultural contact, especially on acculturation. It is about a process of change in attitudes, beliefs, identities and values that individuals experience over-time when they come into continuous and prolonged contact with people from a different culture. There are numerous and excellent reviews of this literature (Celenk \& Van de Vijver, 2014; Ward \& Szabo, 2019). It looks at long term adaptation whereas the culture shock literature is more about immediate and short-term reactions to "the experience of the new".

The popularity and spread of the concept of culture shock remains today. Academic papers with the concept in the title are published regularly from many disciplines including sociology (Akarowha, 2018), clinical psychology (Cupsa, 2018), cross-cultural psychology (Chen, Lin, \& Sawangpattanakul, 2011; Goldstein \& Keller, 2015), management and organizational behavior (Kocak, 2014; Meisel, 2012); tourism (Moufakkir, 2013) and refugee studies (Slonin-Nevo \& Regev, 2015). The literature has also begun to look at neglected groups like the spouses of sojourning people (De Verthelyn, 1995).

This whole research area is embedded in the bigger world of acculturation theory and research which is a multi-disciplinary enterprise and ever-advancing (Ward \& Geeraert, 2016).

The structure of this review is first to consider some definitions in this area and then to briefly review two similar syndromes which produce reactions very similar to culture shock. There follows a discussion on possible explanations of culture shock followed by a discussion of how it is measured in the academic literature. The sixth section deals with the discussion of stages and phases in culture shock as well as culture shock with students in their educational sojourn. The penultimate section, before the conclusion, deals with practical implications of the research in this area.

\section{Definitions}

There is inevitably dispute and debate as to who conceived the concept of culture shock and precisely when this occurred. Dutton (2011) has written a very thoughtful paper tracing the origin of the concept to well before Oberg. Indeed, he notes a number of papers dating to as far back as 1929 who used the term specifically with regard to the immigrant experience. He notes that early researchers compared it to shell shock, but that Oberg was the first to look at the concept in depth. Moreover, he explains why Oberg was interested in the topic given that he was the child of Finish immigrants to Canada, and worked as an anthropologist in Alaska, Brazil, Ecudor, Peru and Uganda. It seems an area of research that is of particular interest to academic who have themselves been 
immigrants (Furnham, 2011).

Over the years various researchers have tried to refine the definition of the term looking at very specific psychological factors or facets that make up the experience (Fitzpatrick, 2016; Smolina, 2012; Winkelman, 2003; Xia, 2009). It has been seen as a loss of one's culture, a marker of moving from one culture to another and as a re-socialisation in another culture. It comes as a "hurtful surprise" to many who travel for various reasons. It involves a dramatic new line of thinking (Meisel, 2012).

It is usually a cross-cultural example of the many life challenges that requires adaptation. It is most often thought of as a function of moving from one country to another but people also talk of corporate culture shock (Furnham, 2011) or the experience of moving from rural to urban parts of the same country.

According to Oberg (1966): "Culture shock is precipitated by the anxiety that results from losing all our familiar signs and symbols of social intercourse. These signs or cues include the thousand and one ways in which we orient ourselves to the situations of daily life: when to shake hands and what to say when we meet people, when and how to give tips, how to give orders to servants, how to make purchases, when to accept and when to refuse invitations, when to take statements seriously and when not. Now these cues which may be words, gestures, facial expressions, customs, or norms are acquired by all of us in the course of growing up and are as much a part of our culture as the language we speak or the beliefs we accept. All of us depend for our peace of mind and our efficiency on hundreds of these cues, most of which we are not consciously aware ..." ( $p$. 179)

Various attempts have been made to "unpack" the definition into discrete but related features (Ward et al., 2001)

1) "Strain due to the effort required to make necessary psychological adaptations.

2) A sense of loss and feelings of deprivation in regard to friends, status, profession and possessions.

3) Being rejected by/and or rejecting members of the new culture.

4) Confusion in role, role expectations, values.

5) Surprise, anxiety, even disgust and indignation after becoming aware of cultural differences.

6) Feelings of impotence due to not being able to cope with the new environment." (Furnham, 2011: p. 7)

Essentially culture shock describes a dramatic adaptation challenge. There are many such challenges across the life span but for many culture shock remains dramatic, intense and unexpected. We have to learn to adapt to a very wide range of life events like moving house, school or country, getting married or divorced, the birth or death of a relative. Often similar factors predict how and to what extent an individual or group adapts to the change.

Number of researchers have documented the various factors that may influ- 
ence the acuteness and chronicity (severity) of culture shock including the degrees of control that travellers have, interpersonal factors (age, appearance, personality, language skills), biological factors (medical care; dietary restrictions), interpersonal factors (social networks; finances) spatio-temporal factors (place of visit; time spent) and geopolitical factors (political tensions, meteorological and seismological factors (Stewart \& Leggat, 1998).

One question is how the academic literate on adaptation in general informs the culture shock literature especially examining those personal characteristics and situations that correlated with healthy vs unhealthy adaptation.

Bochner (1982) attempted to classify individuals in terms of their psychological responses to the host country. He posited that there are four main ways in which people behave when in a new culture:

"Passing"-rejecting the culture of origin and embracing the new culture. The original culture's norms lose their salience and the new culture's norms gain salience. This type of mind-set may be prevalent for migrants looking for employment that have come from war-torn countries and seek a new life.

"Chauvinism"-rejection of the current culture and exaggerating the original. The original culture's norms increase in salience and the new culture's norms decrease in salience. This can cause an increased feeling of nationalism for the individual and can lead to racism, and as a society cause inter-group friction. This type of mind-set is increasingly rare, with people becoming more accepting of other cultures and religions.

"Marginal"-hovering between the two cultures, the individual is not certain of who he/she is. Norms of both cultures are salient but are perceived as mutually incompatible. This leads to mental confusion for the individual, over compensation and conflict and for the society causes reform and social change. Again, this type of mind-set is increasingly rare, with integration into a foreign society being greatly eased.

"Mediating"-synthesizing both cultures. This mind-set is most ideal as it can mediate between both cultures. Norms of both cultures are salient and are perceived as capable of being integrated. This leads to the individual growing personally and society exhibiting higher levels of inter-group harmony and cultural preservation. This is probably the most prevalent mind-set that can be.

The first two responses attempt a sort of defense against shock. Those who try passing are agree to hide their origins, perhaps deny their own culture. The second group may seem to be arrogantly ignorant of the local culture. The ideal situation is where people become culturally "multi-lingual" able to move between cultures as easily as some change languages.

The term culture shock soon took root in the popular imagination. There are well over 50 books with Culture Shock in the title, many published by the Times of Singapore. They each deal with a specific country and have a unique selling point that they are all written by outsiders/foreigners who did not grow up in that country. They are essentially psychological guides to surviving and thriving 
in a new culture.

The popular media has been full of references to culture shock for 50 years. Guides in how to mitigate the effects of culture shock are offered to all sorts of travellers. People recognise it immediately though they are surprised by it. There are many related definitions but they nearly all convey a similar meaning. The concepts quoted are: “disorientation", “anxious confusion”, “disease”, "mental shock" or "transition shock". It is agreed that culture shock is a disorientating experience of suddenly finding that the perspectives, behaviours and experience of an individual or group or whole society are not shared by others. However, it is also agreed that it is a ubiquitous and normal stage in any acculturative adaptive process that all "travellers" experience. Going to "strange places" and losing the power of easy communication can disrupt self-identity, world views and indeed all systems of acting, feeling and thinking.

Indeed, the concept is so well known that there have been studies on "lay theories of culture shock". Goldstein and Keller (2015) found that students tended to attribute culture shock to differences in the external environment (language, communication, and surroundings) rather than to internal affective or cognitive factors (poor stress management, identity confusion, or prejudice). "The tendency to attribute culture shock to internal causes was greater for those with higher levels of cultural competence, whereas low travel experience and interest in foreign language learning predicted the tendency to attribute culture shock to external causes" (p. 187).

However, there are those who criticize the concept. A good example is Fitzpatrick (2017) who rejects what he calls the "billiard ball", essentialist notion of cultures. He argues from a social constructivist perspective which sees the adjustment process of various types and levels. Like researchers of that persuasion he rejects the idea that cultures are distinct entities focusing on the "psychological, sociocultural and discursive nature of social interaction within a dialectic framework" (p. 292). While he describes the well-established success factors in overcoming culture shock, he focusses on how individuals construct and negotiate meaning in their lives. He advocates taking the "culture" out of culture shock preferring the concept of context. Whilst this approach may be seen to correct the simple view that people form culture A will have problems in moving to Culture B, its highly individualistic approach looking at negotiated meanings makes it difficult to understand common experiences and processes.

Many have listed the symptoms of culture shock (cognitive, emotional, physiological reactions) while other researchers have attempted to specify personal factors that seem to predict who and how much individuals suffer from culture shock like Openness, Neuroticism, language proficiency and tolerance for contradiction (Spencer-Rodgers, Williams, \& Peng, 2010).

There are many personal accounts and helpful advice procedures for people to develop better "emotional resilience" to move between cultures (Abarbanel, 2009; Azeez et al., 2004; Barrett, 2009; Bourne, 2009; Green, 2006). This includes 
what people in educational and work environments can, and should, do to lessen the experience of culture shock (Guy \& Patton, 1996).

Culture shock has been studied in many groups including tourists (Court \& King, 1979); students (Gaw, 2000; Sayers \& Franklin, 2008, Willis, 2009; Hu, 2008) and working people (Guy \& Patton, 1996). The costs of expatriate failure have encouraged researchers to try and understand causes as well as reduce the amount of culture shock that results (Pires, Stanton, \& Ostenfeld, 2006).

Culture shock is conceived as a serious, acute and sometimes chronic affective reaction to a new (social) environment. Furnham (2011) has noted there are other closely related "shocking" concepts. These include:

- Invasion shock: this occurs in places where tourists or other visitors suddenly appear in large numbers in a particular setting and overwhelm the locals who become a minority in their own living space. Because the "invaders" retain their cultural morals (of dress, social interaction) they can surprise, frustrate and offend the locals. In this sense they have culture shock without actually going anywhere (Pyvis \& Chapman 2005).

- Reverse culture shock: this occurs when returning to one's home culture to find it different from that which was recalled. Thus, people can never go home again because it does not exist. It is about re-adjusted; re-acculturating and re-assimilating in the home culture (Gaw, 2000). This has also been called Re-entry Shock and the topic of recent research (Gray \& Savicki, 2015).

- Re-professionalisation and Re-licencing shock this occurs when trained professionals do not have their qualifications accepted by a host country and have to be retrained and accepted (Austin, 2007; Austin, Gregory, \& Martin, 2007).

- Business Shock this is the realisation that so many of the subtle business practices vary considerably from one culture to another (Balls, 2005; Pukthuanthong \& Walker, 2007).

- Race culture shock: This concerns being a racial minority in an institution within ones country. Class and race specific styles of dress, speech etc can seriously shock people who do not expect them (Torres, 2009).

- Culture Confusion: This is the term used by Moufakkir (2013) when examining the experience of tourists. He noted other semi-synonymous terms like positive disintegration; culture unrest, culture fluidity, hybridity and fatigue

There remains general agreement about the term however. It is a negative affective, behavioural and cognitive reaction to a new stimulus which is unexpected. It varies between individual in acuity and chronicity.

Whilst it is agreed there is no simple definition of culture shock it needs the following components: It is unexpected and surprising; it is associated with a number of negative emotions; and it leads to an examination of, and attempts to integrate, different understandings of human behaviour. Hence culture may be defined as a sudden, unexpected, and surprising set of mainly negative emotions and cognitions associated with encountering a new environment. 


\section{The Jerusalem and Stendhal Syndrome}

There is a small but fascinating literature sometimes called the Stendhal or Jerusalem syndrome. These are named after a French 19th century author, and the city of Jerusalem, and refer to dramatic emotional responses to art or shrines. As Datta (2017) has noted it is significant physical reaction, nearly always experienced by tourists, when exposed to great art or culturally, historical or very religious places. Hence the Paris, Mecca or Venice syndrome all of which describe the same physiological and psychiatric reaction to places or art.

It was identified by French writer who also introduced the word tourist. The syndrome is characterised by sudden palpitations, dizziness, and paranoia and then extasy and euphoria. Reactions can range from mild emotional reactions to effectively psychosis. Indeed, there is a book written by a Florentine psychiatrist which details the reactions of 106 patients whose reactions to depictions of religious revelations or wars cause their very sudden and severe breakdown (Magherini, 1979).

Datta (2017) mentions other problems as well as "Art Headache", "Culture Overload", "Museum Fatigue" and "Culture Overflow". There is also a paper on "Airport Wandering Syndrome" about people who get lost at airports and show psychotic symptoms (forget their identity, unaware of where they have come from or going to) (Shapiro, 1982).

In a detailed paper by a group of Israeli psychiatrists, the manifestations, and causes of the "Jerusalem Syndrome" are described (Bar-El et al., 2000). Indeed, they describe three types of the syndrome and particularly the Jerusalem syndrome which they note are unconfounded by previous psychotic history or psychopathology. They noted that around 100 tourists are admitted to their medical centre annually of which around half are hospitalised. The syndrome seems to be caused by a change of routine, unfamiliar surroundings, proximity to strangers, inactivity, a sense of isolation and culture clash.

Montanari (2013) also discussed the Kyoto and Mishima syndrome which are reactions to going to these particular cities. However, there is twist, because for the latter the tourists are very confined to pre-set walks and activities such that it is the zoo in reverse, where visitors are effectively caged and observes the sights through bars

There are two important implications of this literature. First, culture-shock type reactions can result from a number of tourist experiences. Second, not only are they unexpected but they can be relatively severe, albeit for a relatively short period.

\section{Explaining Culture Shock}

In their book Furnham and Bochner (1986) found eight different explanations for culture shock and evaluated the power of each "theory" to explain the phenomena.

- Culture shock is essentially the psychology of loss and the phenomenon is 
akin to that of grief or grieving. Thus, culture shock depends mainly on how much one loved, and was attached to, one's mother country or place of origin.

- Locus-of-control type beliefs in fatalism or instrumentation best predict culture shock. The more fatalistic with external locus of control the person has and the culture from which they come the less adaptive they are. Adaptation involves a sense of instrumentalism.

- Selective migration forces are some of the best predictors of culture shock. That is, the more rigorously migrants are self-selected or selected by adaptive factors (education, mental health) for their ability and strength, the better they will be able to adapt. As long as certain hurdles are put in place, they will sort out those likely to adapt well.

- Realistic expectations about what will be encountered are the most important factors in adaptation. The closer the sojourners' expectations about all aspects of their new life and job (social, economic, personal) approximate to reality, the happier they will be and the easier the adjustment.

- Culture shock should be seen as, and calculated by, negative life events, such that the more actual change people experience and have to adapt to, the more likely it is they will experience culture shock. The number and severity of major life differences experienced is a good (negative) predictor of-adaptation and happiness.

- The better, both quantitatively and qualitatively, one's social support network of friends, family and co-nationals, the better will be one's ability to overcome culture shock. Thus if people move with supportive others or into established communities of those with similar backgrounds the sooner they will adapt.

- Value differences between native and foreign culture are the most powerful predictors of adaptation and shock. The closer one approaches the fundamental values about social behavior and desirable outcomes and the behaviours that drive them, the easier it is to adapt.

- The actual social skills one possesses in dealing with people from the native culture are the best predictor of adaptation and shock. It is assumed that having social skills predicts the extent to which they are able to pick up new skills which help in the adaptation process.

Furnham and Bochner (1986) attempt to point out the insights and limitations of each "explanation", favouring the latter four as having most explanatory power. Each explanation has important implications for how one deals with culture shock and the psychological effects of change and transition.

Ward, Bochner and Furnham (2001) noted three theoretical approaches to culture shock. The first is the culture learning perspective which stresses the importance of acquiring culturally relevant social knowledge to cope with, and thrive in, any new society. Thus, to minimize culture shock sojourners need to become communicatively competent in the new culture. They need to master the 
subtleties and nuances of the "hidden language" of cross-cultural interaction to prevent friction and misunderstanding.

The second approach is the stress, coping and adjustment process which focuses on the coping styles of individual sojourners as they attempt to adjust to the new culture. Thus, their personality, social support network, knowledge and skills and personal demography (age, sex) all, in part, how quickly and thoroughly they adapt. As they note "Both macro and micro level variables affect transition and adjustment and characteristics of both the individual and the situation mediate and moderate the appraisal of stress, coping responses and long and short-term outcomes" (p. 96).

The third approach focuses on social identity and inter group relations. The idea is that how people see themselves and their group effects how they deal with those from a different group. Stereotypes attributions for the cause of behaviour and discrimination against "out groups" but in favour of in groups are all seen to be a function of a person's self-identity. It is argued that various individual and social forces influence a person's sense of themselves which, in turn, influence their adaptation to and acculturation in, the new society.

Some researchers have developed and tested simple models to try to predict who suffers most from culture shock (Kaye \& Taylor, 1997). Shupe (2007) proposed a model to understand international student conflict. However, the most sophisticated model has been proposed by Zhou, Jondal-Snape, Topping and Todman (2008).

Table 1 shows the theoretical origin of the eight explanations while Table 2 provides a clear description of the ABC model of Ward et al. (2001).

This academic literature has thrown-up a number of related ideas. One such concept is the culture-distance concept, which states simply that the absolute amount of difference or distance (defined both objectively and subjectively) between a sojourner's own and the host culture is directly proportionally related to the amount of stress or difficulty experienced.

Table 1. Traditional theoretical approaches to culture shock.

\begin{tabular}{lll}
\hline Theory & Epistemological origin & Conceptual formulation \\
\hline Grief and Bereavement & Psychoanalytic tradition & Sees migration as experience of and adaptation to loss \\
Locus of Control & Applied social psychology & Control (Internal/External) predict migration adaptation \\
Selective migration & Socio-biology & Individual fitness and motivation predicts adaptation \\
Expectations & Applied social psychology & Expectancy-values relate to reasons for migration and adjustment \\
Negative life-events & Clinical psychology & Migration involves many stressful life changes, \\
Social support & Clinical psychology & Social and emotional support offers a buffering effect \\
Value difference & Social psychology & Implicit and explicit alue differences lead to poor adaptation \\
Social skills and culture learning & Social psychology & Lacking social skills may cause constant communication problems
\end{tabular}

Adapted from Zhou et al. (2008). 
Table 2. Contemporary theories of intercultural contact.

\begin{tabular}{|c|c|c|c|c|}
\hline Theory & Conceptual Framework & Theoretical Premise & Factors affecting adjustment & Intervention guidelines \\
\hline $\begin{array}{l}\text { Stress and Coping } \\
\text { (Affect) }\end{array}$ & $\begin{array}{l}\text { Cross-cultural travellers } \\
\text { need to develop special coping } \\
\text { strategies to deal with the stress } \\
\text { of migration }\end{array}$ & $\begin{array}{l}\text { All life changes are } \\
\text { constant but inherently } \\
\text { stressful }\end{array}$ & $\begin{array}{l}\text { Adjustment factors involving } \\
\text { personal (demographic, } \\
\text { personality, values) and } \\
\text { situational (e.g. social support) }\end{array}$ & $\begin{array}{l}\text { Training people to develop robust } \\
\text { stress-coping and management } \\
\text { skills }\end{array}$ \\
\hline $\begin{array}{l}\text { Culture Learning } \\
\text { (Behaviour) }\end{array}$ & $\begin{array}{l}\text { Cross-cultural travellers need } \\
\text { to learn culturally relevant } \\
\text { social skills to communicate } \\
\text { in their new settings }\end{array}$ & $\begin{array}{l}\text { Social interaction is a } \\
\text { skilled performance } \\
\text { which has to be learnt } \\
\text { and practiced }\end{array}$ & $\begin{array}{l}\text { Culture specific variables. } \\
\text { knowledge about a new culture, } \\
\text { language/communication } \\
\text { competence, social intelligence } \\
\text { cultural distance. }\end{array}$ & $\begin{array}{l}\text { Preparation, orientation and } \\
\text { culture learning, especially } \\
\text { behavioural-based social skill } \\
\text { training as well as social and } \\
\text { emotional intelligence }\end{array}$ \\
\hline $\begin{array}{l}\text { Social Identification } \\
\text { (Social Cognition) }\end{array}$ & $\begin{array}{l}\text { Cross-cultural transition have } \\
\text { to adjust to changes in cultural } \\
\text { identity and inter-group } \\
\text { relations }\end{array}$ & $\begin{array}{l}\text { Sense of personal and } \\
\text { group identity is a } \\
\text { fundamental issue for } \\
\text { all travellers }\end{array}$ & $\begin{array}{l}\text { Cognitive variables } \\
\text { knowledgeable of the host culture } \\
\text { (History, Religion, Etiquette) } \\
\text { beliefs/attitudes between hosts } \\
\text { and sojourners, cultural similarity, } \\
\text { cultural identity }\end{array}$ & $\begin{array}{l}\text { Enhancing self-esteem, } \\
\text { overcoming barriers } \\
\text { to inter-group harmony, } \\
\text { emphasising inter-group } \\
\text { similarities and identity }\end{array}$ \\
\hline
\end{tabular}

Adapted from Zhou et al. (2008).

Another concept relates to social support and has been described as the functional friendship model which suggests that various friendship networks (host, bicultural and multicultural) serve important psychological functions, which in turn help a sojourner over numerous difficulties. These continue to grow and be explored empirically.

Many researchers have become interested in what individual and groups factors impact on sojourner adjustment using person-environment fit models. Thus Valenzuela and Rogers (2018) noted how the Big Five personality traits related to different acculturation strategies while Geeraert et al. (2019) in a longitudinal study identified Agreeable and Honesty-Humility as important traits in the process of sojourner adjustment.

In an important meta-analysis Wilson, Ward and Fischer (2013) found the Big Five has small to medium effects on cultural competence with all being positive (particularly Extraversion and Openness) except Neuroticism which is be expected.

Many other factors have been proposed like intelligence but there remain relatively few studies of this type

It is true to say that there is no agreed description of the mechanisms underlying culture shock

At this stage most reviewers have simply categorised the types of approaches to the topic Those from a psychoanalytic, social psychological, cross-cultural and organizational psychology background will rely on their preferred concepts and explanations. This may not be seen as a great handicap in the area given the complexity of the phenomenon in different concepts.

\section{The Measurement of Culture Shock}

There were few psychometric tools specifically trying to measure culture shock, 
but these have grown over the last 20 years. Rudmin (2009) reviewed various measures of acculturation and acculturative stress of which there are a number such as the Sociocultural Adaptation Scale (Ward \& Kennedy, 1999). Some researchers like Matsumoto have been very active in this area (Matsumoto et al., 2001, 2003, 2004, 2007). Others worked in this area such as Haslberger (2005) who focused on the measurement of adaptation outcomes in different spheres

Very few set out to measure the concept per se. However, Mumford (1998) and Mumford and Babiker (1998) devised and validated a short 12 item measure divided into Core items and Interpersonal stress items. The questionnaire was validated on 380 British volunteer workers who had gone to 27 different countries. The alpha (internal reliability) for each part was not particularly impressive (.75 and .52) although overall it was an acceptable .79. External criterion validity was established by using the CDI (Culture Difference Index) (Babiker, Cos, \& Miller, 1980). It showed as predicted the greater the cultural difference between British and country visited, the greater the culture shock. It appears to be a simple, albeit fakeable, instrument to get a 'rough-and-ready self-report with little difficulty.

There has been a lot of interest in psychometrics in this area but nearly all the tests are tangentially related to culture shock although one could see why that may be case. For instance a related measure which has attracted a great deal of attention is Culture Intelligence (Ang \& Van Dyne, 2008). This is a 20-item questionnaire that has four subscales and a total score. The subscales are labelled Metacognitive, Cognitive, Motivational, Behavioural and Total. The test has been evaluated for its construct, content, concurrent and predictive validity and reliability. It has also been used in a wide variety of cultures. Thus, for instance it would possible to use this measure as an independent variable seeing how it may predict the acuity and chronicity of culture shock; a mediating or moderator variable between culture shock and later adaptation; as well as dependent variable the showed how culture shock experiences changed subscale and total scores.

Research demonstrates that $\mathrm{CQ}$ is consistent predictor of performance in multicultural settings. Cultural intelligence research has been cited and peer reviewed in more than seventy academic journals (Blasco, Feldt, \& Jakobsen, 2012; Gelfand et al., 2008; Soon et al., 2007; Thomas et al., 2012, 2015).

Numerous papers have examined how CI impacts on culture shock such as that by Chen, Lin, \& Sawangpattanakul (2011) who looked a Philippinos working in Taiwan and showed how CQ was positively related to work performance and negatively related to culture shock (using the Mumford measure) and that, as predicted, culture shock mediated the relationship of CQ and performance. There have also been attempts to develop new measures of CQ such as that by Thomas et al. (2015) who validated their single value measure with three sub-scales (Knowledge, Skills, Metacognition) with over 3500 participants in five language groups round the world. The scale and theory behind it continue to attract a good deal of attention including a meta-analysis and theoretical exten- 
sions (Rockstuhl \& van Dyne, 2018).

The development of robust, valid psychometric measures of culture shock and adaptation are welcome. They can help both researchers and practitioners understand the nature and degree of difficulty experienced by travelers of all kinds. An important paper by Matsumoto and Hwang (2013) reviewed 10 tests of cross-cultural competence. For them: "Adjustment refers to the subjective experiences associated with adaptation, and may be assessed by mood states, self-esteem, self-awareness, physical health, self-confidence, stress, psychological and psychosomatic concerns, early return to one's home country, dysfunctional communication, culture shock, depression, anxiety, diminished school and work performance, and difficulties in interpersonal relationships. In extreme cases, negative adjustment can involve antisocial behavior (gangs, substance abuse, crime) and even suicide" ( $p 850)$

In their review they identified three tests: CQ (mentioned above), the Intercultural Adjustment Scale (ICAPS) with eight constructs, and the Multicultural Personality Questionnaire (MPQ) with seven constructs. They noted various domains that seemed the "active ingredients" in these measures namely openness (flexibity), emotional stability/regulation, empathy and critical thinking.

Yet there is no "let-up" in the development of measures for this area of research. Demes and Geeraet (2014) developed four new scales measuring sociocultural adaptation, psychological adaptation, perceived cultural distance and acculturation adaptation.

Just as in many other areas of psychology there seems to be more of a taste to develop a new instrument rather than test those currently in existence. In some areas of psychology academics have called for a moratorium in "test development". The say that we need to spend more time and effort evaluating what we have before going on to develop more and more tests. It is not difficult to devise a test, but there is a lot of effort that goes into evaluating them. To prove the tests measures what it says it does can take years of careful and expensive data collection.

Indeed, all this activity has led to fallacious thinking. The Jingle-Jangle fallacy refer to the specious idea that two different things are the same because they bear the same name (jingle fallacy) or that two identical or very similar concepts are different because they have different labels (jangle fallacy).

For the psychometrician, the jangle fallacy describes the inference that two tests of whatever sort with different names/labels measure essentially quite different constructs. On the other hand, a jingle fallacy is based on the assumption that two measures that have the same name measure the same construct.

\section{Stages and Phases}

Since Oberg (1960) it has been fashionable to describe the "disease" of culture shock in terms of several stages (Smalley 1963). These attempts have all been descriptive and tend to overlap. 
Oberg (1960) listed four stages of shock:

1) Honeymoon stage: An initial reaction of enchantment, fascination, enthusiasm, admiration and cordial, friendly, superficial relationships with hosts.

2) Crisis. Initial differences in language, concepts, values, familiar signs and symbols lead to feelings of inadequacy, frustration, anxiety and anger.

3) Recovery: The crisis is resolved by several methods, such that the person ends up learning the language and culture of the host country.

4) Adjustment. The sojourner begins to work in and enjoy the new culture, although there may be occasional instances of anxiety and strain.

Others such as Adler (1975) have set out a much more elaborate theory.

Perhaps a more interesting idea is the difference between the $\mathrm{U}$ and $\mathrm{W}$-curve. The idea of the U-curve has been attributed to Lysgaard (1955). He concluded that people go through three phases: initial adjustment, crisis and regained adjustment. If one traces the sojourner's level of adjustment, adaptation and wellbeing over time, a U-shape occurs, such that satisfaction and well-being gradually decline but then increase again. The Wcurve is an extension by Gullahorn \& Gullahorn (1963), who found that once sojourners return to their home country they often undergo a similar re-acculturation process, again in the shape of a $U$, hence the double $\mathrm{U}=\mathrm{W}$.

This has been investigated in many studies (Tamura \& Furnham, 1992). Furnham and Bochner (1986) have pointed out various problems with this literature, notably the vagueness of the description and definition (When is a $U$ not a U?).

In a review of the U-curve literature, Church (1982) reports seven studies and concluded that support for the U-curve hypothesis is weak, inconclusive and overgeneralized. For instance, not all sojourners start off in the phase of supposed adjustment, elation and optimism-some are unhappy, depressed and anxious right from the start (if not before). Secondly, some never become depressed or anxious, enjoying the experience and adjusting to the culture right from the start. Thirdly, where there are U-curves, they are of dramatically different shape-some are flat, others tall, and all are irregular.

Bochner et al. (1980) argued that the sojourn U-shape can be derived from the distinction between observing a new culture and participating in it. When the sojourner's role as an observer shifts to that of a participant, a transition that is inevitable, the initial fascination with the new culture similarly shifts to now having to cope with it, which in Bochner's terms means learning its salient features.

Some sojourners never learn the new culture, nor develop reciprocal role relationships with their hosts. Other sojourners do acquire the social skills of the new society and develop genuine contacts with their hosts. Others again stand somewhere between the two extremes. Thus, the rate of culture-learning is not uniform across sojourners but depends on all the contact variables described earlier. This may explain why the U-curve is not supported in some studies, since some individuals may not experience it, such as sophisticated culture tra- 
vellers who immediately become full participants and hence their curve never drops. Likewise, there are some very poor culture-learners who fail to participate in their new society, and their curve of satisfaction would therefore never rise.

The re-entry U-curve can be derived from the notion of contradictory role demands. In one study Gaw (2000) looked at reverse culture shock in American students returning home. Many felt alienated, lonely, depressed and confused. Bochner et al. (1980) have shown that returning expats anticipate that they will be subjected to contradictory social expectations. In particular, they think that there will be some ambivalence in the treatment they will receive from their professional, peer and family groups. Again, the rate of resolving these role conflicts may vary with certain circumstances and could account for the absence of a W-curve in some studies. Furnham and Bochner (1986) suggested the successful culture-learner should exhibit a typical U-curve and, after re-entry, a W-curve. Experienced culture travelers should show a flat "curve" and unsuccessful ones a declining curve during sojourn and a rising one after re-entry.

There is still an interest in the stages of adaptation (Brown \& Holloway, 2008), though the acceptance of stage-wise theories in many areas of psychology is declining.

\section{The Educational Sojourn and Culture Shock}

Students travelling from one country to another has been established for centuries, particularly in Europe, it is not until comparatively recently that they have become the focus of study (Ward, Bochner \& Furnham, 2001; Miller \& El-Aidi, 2008). There are various books exclusively on foreign students which look at the psychology of their experience. (Akarowhe, 2018; McNamara \& Harris, 1997; van Tilburg \& Vingerhoets, 1997). Indeed, they formed the basis of some of the earliest theories and measures in the area (Sandhu \& Asrabadi, 1994).

One recent review study on the effect of culture shock on adolescent students suggested many negative effects: communication defects, academic retardation, conflict, emotional imbalance, deviance and aloofness and withdrawal (Akarowhe, 2018). The research in this area continues with a particular interest in which factors are most closely related to cross cultural adaptation (Wang et al., 2018).

Much of this research suggests that many students feel classic alienation especially feelings of powerlessness, meaningless, and social estrangement while being surrounded by the "superficial pleasantries" of their hosts. Most of the research studies have been aimed at looking at the affective, behavioral and cognitive consequences of cross-cultural transition in sojourners and have attempted to establish which individual, interpersonal, social, structural and economic factors best predict adjustment.

Practitioners have tried to draw implications for helping foreign students, or travelers of any kind (Furnham, 2011). First, that counselling should be proactive, not reactive and seek out international students who may be vulnerable. 
Second, guidance services should be continuous and comprehensive, not simply confined to orientation sessions soon after arrival. Third, that alternative, less stigmatised approaches should be available through less formal and clinical contacts, such as interest or friendship groups. Fourth, students should be encouraged to become involved in their own adaptation process as well as the education process as a whole. Fifth, the idea of the buddy system, so long used in the American army should be established. Sixth, students could be encouraged to feel a certain amount of empowerment through communication workshops set up for them. Seventh, counsellors should be sensitive and trained in culture differences, specifically the presentation of psychological problems. Indeed, there are so many orientation programmes now available at universities that there is an active research programme in measuring their efficacy (McKinlay, Pattison, \& Gross, 1996).

It is perhaps no surprise that educational institutions have established orientation and counselling programmes for their international students. Some studies have reported incidence of fairly severe breakdown (Janca \& Hetzer, 1992).

One area of research that is theoretically important is the work on foreign student friendship networks. Bochner and his co-workers (Bochner, McLeod, \& Lin, 1977; Furnham \& Bochner, 1986) have shown some interesting trends in the friendship networks of overseas students. In a study of foreign students in Hawaii, Bochner et al. (1977) developed a functional model of overseas students' friendship patterns, stating that the sojourners belong to three distinct social networks

Recently Brunsting, Zachry and Takeucci (2018) published a systematic review of 30 empirical studies on international student psychosocial adjustment to American universities published in the years 2009-2018. They suggested that the literature needs to be more informed by motivational and developmental theories. They also stress the importance on examining the importance of social support and friendship networks on foreign students sense of belonging and well-being.

\section{Practical Implications}

Many organisations "deal with travelers" of one sort or another: airlines and shipping companies; tourists companies and hotels; businesses that employ foreign labourers or who send their staff around the world; educational institutions and charities who deal with refugees and migrants. They need to be able to recognize and help with problems of culture shock.

Some important implications of findings from this paper include: first, nearly every travellers experiences and is therefore normal and needs normalizing. Some people are likely to experience it more than others, particularly older, less educated and well-travelled people who move from and to societies that are very different in terms of economics, politics and religion. Those with a history of mental illness or poor resilience are more vulnerable and can be identifies for 
extra help. Second, these symptoms often include anxiety and depression and may include a range of psychosomatic illness and in some instances. psychotic symptoms. This may lead to a number of psychosomatic illnesses. Third, they occur very soon after arriving and tend to get worse before they get better. People need to be forewarned and know what to expect. More importantly organisations need to put in most effort to help not kust after people arrive in their new situation but three to six months later. Fourth, whilst they have a strong need to be with others like them (co-nationals, co-religionists; co-speakers) this may delay their adaptation to the new culture. Fifth, institutions that help those that experience culture shock need to appreciate the cost-benefit analysis on investment in both prevention and cure.

\section{Conclusion}

Culture shock is a reaction to new environments, experiences and people: it is surprising, stressful and requires adaptation. Various patterns in the literature have begun to emerge. Although there are no grand theories attempting to explain this phenomenon, various concepts have been put forward to predict the acuity and chronicity of sojourner distress through culture shock.

Psychological research into sojourner adjustment to culture shock is comparatively new. Many of the early papers were descriptive and even autobiographical. Certainly, it is not easy to do research in the area which involves finding culture travelers and then following their progress over time. Further, there were a shortage of articles in the area. Large-scale, multi-factorial, longitudinal studies, which are theory-derived, may help considerably to identify the problems of increasing numbers of sojourners the world over. It is also important that future research is multi-disciplinary using the concepts and techniques from many disciplines from anthropology to medicine.

It is a complex and difficult area in which to do good academic research one of increasing importance as geographic mobility increases all around the world. Organizations that move their staff a great deal (diplomats, business people, mining companies) know the cost to physical and mental health of those employees who do not cope well with culture shock. Hence the investment in programs which help prevent or mitigate against it is money well spent.

The research area is complicated because it is both "pure" and applied, and of interest to academics from very different disciplines with their own theoretical lenses and preferences as well as preferred research style.

Theoretically the area is demanding particularly or cross-cultural psychology as it requires the old problem of defining culture. As described in the sections on definition and explanation there remains a number of interesting theoretical debates and disagreements at the very heart of the concept.

Despite this it is clear from the number of meta-analyses and systematic reviews that field is progressing and that our knowledge of the culture shock phenomenon can and does help to inform those who have to deal with it. 


\section{Conflicts of Interest}

The author declares no conflicts of interest regarding the publication of this paper.

\section{References}

Abarbanel, J. (2009). Moving with Emotional Resilience between and within Cultures. Intercultural Education, 20, S133-S141. https://doi.org/10.1080/14675980903371035

Adler, P. (1975). The Transitional Experience: An Alternative View of Culture Shock. Journal of Humanistic Psychology, 15, 13-23. https://doi.org/10.1177/002216787501500403

Akarowhe, K. (2018). Effects and Remedies to Cultural Shock on the Adolescent Students. Sociology International Journal, 2, 306-309. https://doi.org/10.15406/sij.2018.02.00063

Ang, S., \& Van Dyne, L. (2008). Conceptualization of Cultural Intelligence: Definition, Distinctiveness, and Nomological Network. In S. Ang, \& L. Van Dyne (Eds.), Handbook of Cultural Intelligence: Theory, Measurement, and Applications (pp. 3-15). Armonk, NY: M. E. Sharpe.

Austin, Z. (2007). Geographical Migration, Psychological Adjustment, and Re-Formation of Professional Identity: The Double Culture Shock Experience of International Pharmacy Graduates in Ontario (Canada). Globalisation, Societies and Education, 5, 239-255. https://doi.org/10.1080/14767720701427145

Austin, Z., Gregory, P., \& Martin, C. (2007). Negotiation of Interprofessional Culture Shock: The Experiences of Pharmacists Who Become Physicians. Journal of Interprofessional Care, 21, 83-93. https://doi.org/10.1080/13561820600874817

Azeez, B., Kerne, A., Southern, J., Summerfield, B., Aholu, I., \& Sharmin, E. (2004). Sharing Culture Shock through a Collection of Experiences. https://doi.org/10.1145/996350.996468

Babiker, I. E., Cox, J. L., \& Miller, P. M. (1980). The Measurement of Cultural Distance and Its Relationship to Medical Consultations, Symptomatology and Examination Performance of Overseas Students at Edinburgh University. Social Psychiatry, 15, 109-116. https://doi.org/10.1007/BF00578141

Balls, A. (2005). Business Culture Shock.

Bar-el, Y., Durst, R., Katz, G., Zislin, J., Strauss, Z., \& Knobler, H. (2000). Jerusalem Syndrome. British Journal of Psychiatry, 176, 86-90. https://doi.org/10.1192/bjp.176.1.86

Barrett, S. (2009). Culture Shock. http://www.employeebenefits.co.uk

Blasco, M., Feldt, L., \& Jakobsen, M. (2012). If Only Cultural Chameleons Could Fly Too. A Critical Discussion of the Concept of Cultural Intelligence. International Journal of Cross Cultural Management, 12, 229-245. https://doi.org/10.1177/1470595812439872

Bochner, S. (1982). The Social Psychology of Cross-Cultural Relations. In S. Bochner (Ed.), Cultures in Contact: Studies in Cross-Cultural Interaction (pp. 5-44). Oxford: Pergamon. https://doi.org/10.1016/B978-0-08-025805-8.50008-1

Bochner, S., McLeod, B., \& Lin, A. (1977). Friendship Patterns of Overseas Students. A Functional Model. International Journal of Psychology, 12, 277-297. https://doi.org/10.1080/00207597708247396

Bourne, L. (2009). Culture Shock. Projects Spanning Cultures Need More than Just a Good Translator. http://www.PMI.ORG

Brown, L., \& Holloway, I. (2008). The Initial Stage of the International Sojourn: Excitement or Culture Shock? British Journal of Guidance \& Counselling, 36, 33-49. 
https://doi.org/10.1080/03069880701715689

Brunsting, N., Zachry, C., \& Takeuchi, R. (2018). Predictors of Undergraduate International Student Psychosocial Adjustment to US Universities. International Journal of Intercultural Relations, 66, 22-33. https://doi.org/10.1016/j.ijintrel.2018.06.002

Celenk, O., \& Van de Vijver, F. J. R. (2014). Assessment of Acculturation and Multiculturalism: An Overview of Measures in the Public Domain. In V. Benet-Martínez, \& Y. Y. Hong (Eds.), Oxford Handbook of Multicultural Identity: Basic and Applied Perspectives (pp. 205-226). Oxford: Oxford University Press. https://doi.org/10.1093/oxfordhb/9780199796694.013.001

Chen, A., Lin, Y.-C., \& Sawangpattanakul, A. (2011). The Relationship between Cultural Intelligence and Performance with the Mediating Effect of Culture Shock. International Journal of Intercultural Relations, 35, 246-258.

https://doi.org/10.1016/j.ijintrel.2010.09.005

Church, A. (1982). Sojourner Adjustment. Psychological Bulletin, 91, 540-572. https://doi.org/10.1037/0033-2909.91.3.540

Cohen, E. (2007). Surviving the Culture Shock.

Court, D., \& King, M. (1979). Some Correlates of Culture Shock among American Tourists in Africa. International Journal of Intercultural Relations, 3, 211-225. https://doi.org/10.1016/0147-1767(79)90065-8

Crawley, H., \& Skleparis, D. (2018). Refugees, Migrants, Neither Both. Journal of Ethnic and Migrant Studies, 4, 48-64. https://doi.org/10.1080/1369183X.2017.1348224

Cupsa, I. (2018). Culture Shock and Identity. Transactional Analysis Journal, 48, 181-191. https://doi.org/10.1080/03621537.2018.1431467

Datta, S. (2017). Stendhal Syndrome. Psychology and Cognitive Sciences, 3, 66-73. https://doi.org/10.17140/PCSOJ-3-125

De Verthelyn, R. (1995). International Students' Spouses: Invisible Sojourners in the Culture Shock Literature. International Journal of Intercultural Relations, 19, 387-411. https://doi.org/10.1016/0147-1767(95)00028-A

Demes, K., \& Geeraert, N. (2014). Measures Matter: Scales for Adaptation, Cultural Distance and Acculturation Orientation Revisited. Journal of Cross-Cultural Psychology, 45, 91-109. https://doi.org/10.1177/0022022113487590

Dutton, E. (2011). The Significance of British Columbia to the Origins of the Concept of "Culture Shock". BC Studies, 171, 111-129.

Engle, R., Dimitriadi, N., \& Sadrieh, F. (2012). Cultural Intelligence: Antecedents and Propensity to Accept a Foreign-Based Job Assignment. Journal of Applied Management and Entrepreneurship, 17, 63-79.

Fitzpatrick, J. (2016). Understanding Culture Shock. PhD, Newcastle: Newcastle University.

Fitzpatrick, J. (2017). Taking the "Culture" out of "Culture Shock". Critical Perspectives on International Business, 13, 278-298. https://doi.org/10.1108/cpoib-01-2017-0008

Furnham, A. (1984). Tourism and Culture Shock. Annals of Tourism Research, 11, 41-57. https://doi.org/10.1016/0160-7383(84)90095-1

Furnham, A. (2011). Culture Shock: Literature Review, Personal Statement and Relevance for the South Pacific. Journal of Pacific Rim Psychology, 4, 87-94. https://doi.org/10.1375/prp.4.2.87

Furnham, A., \& Bochner, S. (1986). Culture Shock. London: Methuen.

Furukawa, T. (1997). Sojourner Adjustment. Journal of Nervous and Mental Diseases, 
185, 263-268. https://doi.org/10.1097/00005053-199704000-00007

Furuya-Kanamori, L., Mills, D., Sheridan, S., \& Lau, C. (2017). Medical and Psychological Problems Faced by Young Australian Gap Year Travelers. Journal of Travel Medicine, 24, 1-5. https://doi.org/10.1093/jtm/tax052

Gaw, K. F. (2000). Reverse Culture Shock in Students Returning from Overseas. International Journal of Intercultural Relations, 24, 83-104. https://doi.org/10.1016/S0147-1767(99)00024-3

Geeraert, N., Li, R., Ward, C., Gelfand, M., \& Demes, K. (2019). A Tight Spot: How Personality Moderates the Impact of Social Norms on Sojourner Adaptation. Psychological Science, 30, 333-342. https://doi.org/10.1177/0956797618815488

Gelfand, M. J., Imai, L., \& Fehr, R. (2008). Thinking Intelligently about Cultural Intelligence: The Road Ahead. In S. Ang, \& L. Van Dyne (Eds.), Handbook of Cultural Intelligence: Theory, Measurement, and Applications (pp. 375-387). Armonk, NY: ME Sharpe.

Goldstein, S., \& Keller, S. (2015). U.S. College Students' Lay Theories of Culture Shock. International Journal of Intercultural Relations, 47, 187-194.

https://doi.org/10.1016/j.ijintrel.2015.05.010

Gray, K., \& Savicki, V. (2015). Study Abroad Reentry: Behaviour, Affect and Cultural Distance. Interdisciplinary Journal of Study Abroad, 26, 264-278.

Green, R. (2006). Culture Shock. http://www.foodmanufacture.co.uk

Gullahorn, J. T., \& Gullahorn, J. E. (1963). An Extension of the U-Curve Hypothesis. Journal of Social Issues, 19, 33-47. https://doi.org/10.1111/j.1540-4560.1963.tb00447.x

Guy, B. S., \& Patton, W. E. (1996). Managing the Effects of Culture Shock and Sojourner Adjustment on the Expatriate Industrial Sales Force. Industrial Marketing Management, 25, 385-393. https://doi.org/10.1016/0019-8501(96)00040-5

Haslberger, A. (2005). Facets and Dimensions of Cross-Cultural Adaptation. Personnel Review, 32, 85-109. https://doi.org/10.1108/00483480510571897

$\mathrm{Hu}, \mathrm{X}$. Q. (2008). The Culture Shock That Asian Students Experience in Immersion Education. Changing English, 15, 101-105. https://doi.org/10.1080/13586840701825378

Janca, A., \& Hetzer, J. (1992). Psychiatric Morbidity of Foreign Students in Yugoslavia. International Journal of Social Psychiatry, 38, 287-292. https://doi.org/10.1177/002076409203800407

Kaye, M., \& Taylor, S. (1997). Expatriate Culture Shock in China: A Study in the Beijing Hotel Industry. Journal of Managerial Psychology, 12, 496-510. https://doi.org/10.1108/02683949710189102

Kocak, M. (2014). Management of Culture Shock. Amsterdam: De Gruyter Open. https://doi.org/10.2478/cris-2014-0011

Lysgaard, S. (1955). Adjustment in a Foreign Society: Norwegian Fulbright Grantees Visiting the United States. International Social Science Bulletin, 7, 45-51.

Magherini, G. (1979). Syndrome di Stendhal. Milan: Fettrinelli.

Matsumoto, D., \& Hwang, H. (2013). Assessing Cross-Cultural Competence. Journal of Cross-Cultural Psychology, 44, 849-873. https://doi.org/10.1177/0022022113492891

Matsumoto, D., Leroux, J. A., Bernhard, R., \& Gray, H. (2004). Unraveling the Psychological Correlates of Intercultural Adjustment Potential. International Journal of Intercultural Relations, 28, 281-309. https://doi.org/10.1016/j.ijintrel.2004.06.002

Matsumoto, D., LeRoux, J. A., Iwamoto, M., Choi, J. W., Rogers, D., Tatani, H., \& Uchida, H. (2003). The Robustness of the Intercultural Adjustment Potential Scale (ICAPS). 
International Journal of Intercultural Relations, 27, 543-562.

https://doi.org/10.1016/S0147-1767(03)00053-1

Matsumoto, D., LeRoux, J. A., Ratzlaff, C., Tatani, H., Uchida, H., Kim, C., \& Araki, S. (2001). Development and Validation of a Measure of Intercultural Adjustment Potential in Japanese Sojourners: The Intercultural Adjustment Potential Scale (ICAPS). International Journal of Intercultural Relations, 25, 483-510. https://doi.org/10.1016/S0147-1767(01)00019-0

Matsumoto, D., LeRoux, J. A., Robles, Y., \& Campos, G. (2007). The Intercultural Adjustment Potential Scale (ICAPS) Predicts Adjustment above and beyond Personality and General Intelligence. International Journal of Intercultural Relations, 31, 747-759. https://doi.org/10.1016/j.ijintrel.2007.08.002

McGhee, D. (2006). Getting "Host" Communities on Board. Journal of Ethic and Migration Studies, 32, 111-127. https://doi.org/10.1080/13691830500335341

McKinlay, N., Pattison, H., \& Gross, H. (1996). An Exploratory Investigation of the Effects of a Cultural Orientation Programme on the Psychological Well-Being of International University Students. Higher Education, 31, 379-395. https://doi.org/10.1007/BF00128438

McLaren, L., \& Paterson, I. (2019). Generation Change and Attitudes to Immigration. Journal of Ethic and Migration Studies. https://doi.org/10.1080/1369183X.2018.1550170

McNamara, D., \& Harris, R. (1997). Overseas Students in Higher Education. London: Routledge.

Meisel, S. (2012). The Culture Shock of Thinking and Learning. Organisational Management Journal, 9, 112-113. https://doi.org/10.1080/15416518.2012.687993

Miller, S., \& El-Aidi (2008). Culture Shock: Causes and Symptoms. International Business Research, 1, 26-37. https://doi.org/10.5539/ibr.v1n1p26

Montanari, A. (2013). Guidebooks and Travel Stories Interpretations and Emotional Reactions. International Review of Social Sciences and Humanities, 5, 123-134.

Moufakkir, O. (2013). Culture Shock, What Culture Shock? Tourist Studies, 13, 322-340. https://doi.org/10.1177/1468797613498166

Mumford, D. B. (1998). The Measurement of Culture Shock. Social Psychiatry and Psychiatric Epidemiology, 33, 149-154. https://doi.org/10.1007/s001270050037

Mumford, D. B., \& Babiker, I. (1998). Validation of a Self-Administered Version of the Cultural Distance Questionnaire among Young British Volunteers Working Overseas. European Journal of Psychiatry, 12, 244-253.

Oberg, K. (1966). Culture Shock: Adjustment to New Cultural Environments. Practical Anthropology, 7, 177-182. https://doi.org/10.1177/009182966000700405

Pires, G., Stanton, J., \& Ostenfeld, S. (2006). Improving Expatriate Adjustment and Effectiveness in Ethnically Diverse Countries: Marketing Insights. Cross Cultural Management: An International Journal, 13, 156-170. https://doi.org/10.1108/13527600610662339

Pukthuanthong, K., \& Walker, T. (2007). Venture Capital in China: A Culture Shock for Western Investors. Management Decision, 45, 708-731. https://doi.org/10.1108/00251740710745999

Pyvis, D., \& Chapman, A. (2005). Culture Shock and the International Student "Offshore". Journal of Research in International Education, 4, 23-42. https://doi.org/10.1177/1475240905050289

Rockstuhl, T., \& Dyne, L. (2018). The Bi-Factor Theory of the Four-Factor of Cultural 
Intelligence. Organisational Behaviour and Human Decision Processes, 148, 124-144. https://doi.org/10.1016/j.obhdp.2018.07.005

Rudmin, F. (2009). Constructs, Measurements and Models of Acculturation and Acculturative Stress. International Journal of Intercultural Relations, 33, 106-123. https://doi.org/10.1016/j.ijintrel.2008.12.001

Sam, D., \& Berry, J. (2010). Acculturation: When Individuals and Groups of Different Cultural Backgrounds Meet. Perspectives on Psychological Science, 5, 472-481. https://doi.org/10.1177/1745691610373075

Sandhu, D., \& Asrabadi, B. (1994). Development of an Accumulative Stress Scale for International Students: Preliminary Findings. Psychological Reports, 75, 435-448. https://doi.org/10.2466/pr0.1994.75.1.435

Sayers, J., \& Franklin, T. (2008). Culture Shock! Cultural Issues in a Tertiary Course Using Reflective Techniques. Reflective Practice, 9, 79-88. https://doi.org/10.1080/14623940701816675

Shapiro, S. (1982). Airport Wandering as a Psychotic Symptom. Psychiatrica Clinica, 15, 173-176. https://doi.org/10.1159/000283937

Shupe, E. I. (2007). Clashing Cultures: A Model of International Student Conflict. Journal of Cross-Cultural Psychology, 38, 750-771. https://doi.org/10.1177/0022022107308996

Slonim-Nevo, V., \& Regev, S. (2015). Risk Factors Associated with Culture Shock among Asylum Seekers from Darfur. Journal of Refugee Studies, 29, 117-138. https://doi.org/10.1093/jrs/fev009

Smolina, T. L. (2012). Symptoms of Culture Shock: Overview and Classification. Psychological-Educational Studies, No. 3.

Soon, A., Van Dyne, L., Koh, C., Yee Ng, K., Templer, K., Tay, C., \& Chandrasekar, A. (2007). Cultural Intelligence: Its Measurement and Effects on Cultural Judgement and Decision Making, Cultural Adaption and Task Performance. Management and Organisation Review, 3, 335-371. https://doi.org/10.1111/j.1740-8784.2007.00082.x

Spencer-Rodgers, J., Williams, M. J., \& Peng, K. (2010). Cultural Differences in Expectations of Change and Tolerance for Contradiction: A Decade of Empirical Research. Personality and Social Psychology Review, 14, 296-312. https://doi.org/10.1177/1088868310362982

Tamura, T., \& Furnham, A. (1992). Re-Adjustment of Japanese Returning Children from an Overseas Sojourn. Social Science and Medicine, 36, 1181-1186. https://doi.org/10.1016/0277-9536(93)90238-Y

Thomas, D. C., Liao, Y., Aycan, Z., Cerdin, J.-L., Pekerti, A. A., Ravlin, E. C., Vijver, F. et al. (2015). Cultural Intelligence: A Theory-Based, Short Form Measure. Journal of International Business Studies, 46, 1099-1118. https://doi.org/10.1057/jibs.2014.67

Thomas, D., Stahl, G., Ravlin, C. et al. (2012). Development of the Cultural Intelligence Assessment. In Mobley (Ed.), Advances in Global Leadership (pp. 155-178). Bingley: Emerald Group. https://doi.org/10.1108/S1535-1203(2012)0000007011

Titzmann, P., \& Lee, R. (2018). Adaptation of Young Immigrants. European Psychologist, 23, 72-82. https://doi.org/10.1027/1016-9040/a000313

Torres, K. (2009). “Culture Shock”: Black Students Account for Their Distinctiveness at an Elite College. Ethnic and Racial Studies, 32, 883-905. https://doi.org/10.1080/01419870701710914

Valenzuela, M., \& Rogers, S. (2018). Strategizing Personality Traits: An Acculturation Approach to Person-Environment Fit and Expatriate Adjustment. International Journal of Human Resource Management. https://doi.org/10.1080/09585192.2018.1526201 
Van Tilburg, M., \& Vingerhoets, A. (1997). Psychological Aspects of Geographic Movement. Tilburg: Tilburg University Press. https://doi.org/10.1037/e537052011-002

Wang, Y., Li, T., Noltemeyer, A., Wang, A., Zhang, J., \& Shaw, K. (2018). Cross-Cultural Adaptation of International College Students in the United States. Journal of International Students, 2, 821-842. https://doi.org/10.32674/jis.v8i2.116

Ward, C., \& Kennedy, A. (1999). The Measurement of Sociocultural Adaptation. International Journal of Intercultural Relations, 23, 659-677. https://doi.org/10.1016/S0147-1767(99)00014-0

Ward, C., \& Szabo, A. (2019). Affect, Behavior, Cognition and Development: Adding to the Alphabet of Acculturation. In D. Matsumoto, \& S. Hwang (Eds.), Handbook of Culture and Psychology. Oxford: Oxford University Press.

Ward, C., Bochner, S., \& Furnham, A. (2001). The Psychology of Culture Shock. London: Routledge.

Willis, W. (2009). Culture Shock: A New Company Even Seems to Speak a Different Language. http://www.onwallstreet.com

Xia, J. (2009). Analysis of Impact of Culture Shock on Individual Psychology. International Journal of Psychological Studies, 1, 97-101. https://doi.org/10.5539/ijps.v1n2p97

Zhou, Y., Jindal-Snape, D., Topping, K., \& Todman, J. (2008). Theoretical Models of Culture Shock and Adaptation in International Students in Higher Education. Studies in Higher Education, 33, 63-75. https://doi.org/10.1080/03075070701794833 